$\xi=-1$

\title{
Comparison between unit cell and plane strain models of stone column ground improvement
}

\author{
Maryam Gaber ${ }^{1 *}$, Anuar Kasa ${ }^{1}$, Norinah Abdul Rahman ${ }^{1}$, Jamal M. A. Alsharef ${ }^{1}$ \\ ${ }^{1}$ Department of Civil and Structural Engineering, Universiti Kebangsaan Malaysia, Bangi, Selangor 43600, Malaysia \\ *Corresponding author E-mail: mm_gaber@yahoo.com
}

\begin{abstract}
This article presents a comparative study of the behaviour of clayey soil reinforcements using stone column ground improvement by means of numerical analyses. Two-dimensional finite element analyses with commercially available software, PLAXIS, were performed on end-bearing stone columns using 15-noded triangular elements to investigate the impact of the modelling type on the stress concentration ratio and failure mechanism of an improved foundation system. Consolidation analyses were conducted throughout the study using Mohr-Coulomb's criterion. The computed values of the stress concentration ratios were compared for different key parameters, including the diameters of stone columns, c/c spacing of columns, friction angle of stone column material, and undrained cohesion of soft soil. The major conclusions of this study were that the stone column in the unit cell model shared between 2.5 to 3.14 times more loads than the surrounding soil, whilst in the plane strain model it shared between 1.7 to 2.9 times more loads. The use of plane strain approach to model the stone column gave a more comprehensive representation of the stress distribution and load transfer between the soil and columns, in addition to being a better method than the unit cell concept to evaluate the failure mode in this system.
\end{abstract}

Keywords: Stone Column; Unit Cell; Plane Strain; Stress Concentration Ratio; Numerical Analysis.

\section{Introduction}

Stone columns play a definite role in the area of ground improvement. Stone columns are best suited for the reinforcement of sites involving soft clays and soft compressible silts, and for loose, silty sands. So far, the design of stone columns is still limited to empirical and past experiences, where practice plays an important role in the design. The stone column technique of ground treatment has proven to be successful in improving the stability of embankments and natural slopes, increasing the bearing capacity, reducing total and differential settlements, mitigating the potential for liquefaction as well as improving shear resistance. Since most of the stone column designs that have been adopted are based on the unit cell concept, so the authors in this study tried to examine the accuracy of this concept by comparing it to the plane strain model. The unit cell (axisymmetric model) involves a single stone column with its equivalent modelled circular influence zone [1], whilst in the plane strain model; the cylindrical columns are designed as stone trenches, which are widely used below long loads like embankments [2].

The stress concentration ratio SCR is one of the most important factors in the design of stone columns. Since there is no accurate method for obtaining a rational estimate of this ratio, it has to be determined either through an empirical estimation of field measurements or based on an engineer's previous experience. Generally, the stress distribution is defined in terms of the SCR, and is expressed as:

$$
\mathrm{SCR}=\frac{\sigma_{\mathrm{C}}}{\sigma_{\mathrm{s}}}
$$

where: $\sigma_{c}$ is the stress in the column, and $\sigma_{g}$ is the stress in the surrounding soil.

As the stone column is stiffer than the natural soil, the stress will be concentrated in the stone column with an accompanying reduction in stress in the surrounding soil [3]. Numerous studies have been carried out into the behaviour of stone columns, and they have shown that the stress concentration ratio for stone columnreinforced foundations range typically between 2 to 6 , with the usual values being 3 or 4 [4], [5]. On the other hand, Greenwood [6] obtained a much different result, where very soft clay at a low stress level produced a very high SCR of 25. However, Abusharar and Han [7] reported that below an embankment (close to a flexible foundation), a stress concentration ratio of 1.0 is reasonable and conservative. In addition, several parameters have a great influence on the SCR, as examined by numerous researchers. For instance, $\mathrm{Ng}$ [8] studied the effect of an applied load on the SCR, and stated that as the load was increased, a very small increase was noted in the SCR, i.e. $\mathrm{SCR}=3.9$ to 4 for $\mathrm{q}=50$ to $400 \mathrm{kPa}$, respectively. Ichmoto [9] and Kim [10] drew the same conclusions, while other researchers like Watts et al. [11] reported that, based on a field load test; the increase in the stress concentration ratio was due to the increased load. However, Bergado et al. [12] suggested the opposite.

In this study, a series of 2D finite element analyses using the software package, PLAXIS, was employed to simulate a single and group of end-bearing stone columns in soft clay soil. In addition, the paper focused on the factors influencing the SCR and load transfer in the unit cell and plane strain models. Furthermore, the study highlighted the main difference between using a unit cell and plane strain approach in numerical models. 


\section{Case study description}

The selected case study was the Lebuhraya Pantai Timur 2 (LPT2) project, which is a continuation of the first phase of the East Coast Expressway (LPT1) between Karak and Jabor (in Malaysia). The embankments used in this project have heights varying from 10 to $12.5 \mathrm{~m}$, with a minimum top width of $32 \mathrm{~m}$, and side slopes with a gradient of $1 \mathrm{~V}: 2 \mathrm{H}$. Berms, with a width of $2 \mathrm{~m}$ and height of more than $5 \mathrm{~m}$, are provided on both sides of the embankments, as can be seen in a typical cross section of the geometry of the embankment in Figure 1. The presence of clayey silts up to a depth of $8 \mathrm{~m}$ with shear strength values varying between 8 to $11 \mathrm{kPa}$ posed serious problems with regard to stability and long-term settlement Since the soil with these properties was unable to safely support the required height of the embankment, so, the vibro replacement technique was adopted for the treatment of the underlying soft soil. A stone column with a diameter of $1 \mathrm{~m}$ was used for the treatment, depending on variations in the road geometry and soil condition, where the columns were distributed by a square grid pattern with a $2 \mathrm{~m}$ c/c spacing.
The results of a typical single-column plate load test that was carried out on the project are presented in Figure 2. In the first loading cycle, the allowable design load was applied and maintained for a period of $24 \mathrm{~h}$, while in the second cycle, a maximum load of 1.5 times the design load was applied. The acceptable requirement for the load test was that the settlement should not exceed $50 \mathrm{~mm}$ under the allowable load design and $80 \mathrm{~mm}$ under 1.5 times the allowable design load.

The construction of embankments over soft soil is often done in stages to ensure their stability and to minimize the postconstruction settlement, as indicated in Figure 3. The duration of each stage includes two parts, namely, the construction time and the waiting time. The waiting time is set in order to allow for the partial dissipation of excess pore water pressure. The modelling was extended to 1000 days after the end of the second stage in consideration of the serviceability condition (long-term). More detailed information about this case history can be found in Qasim [13].

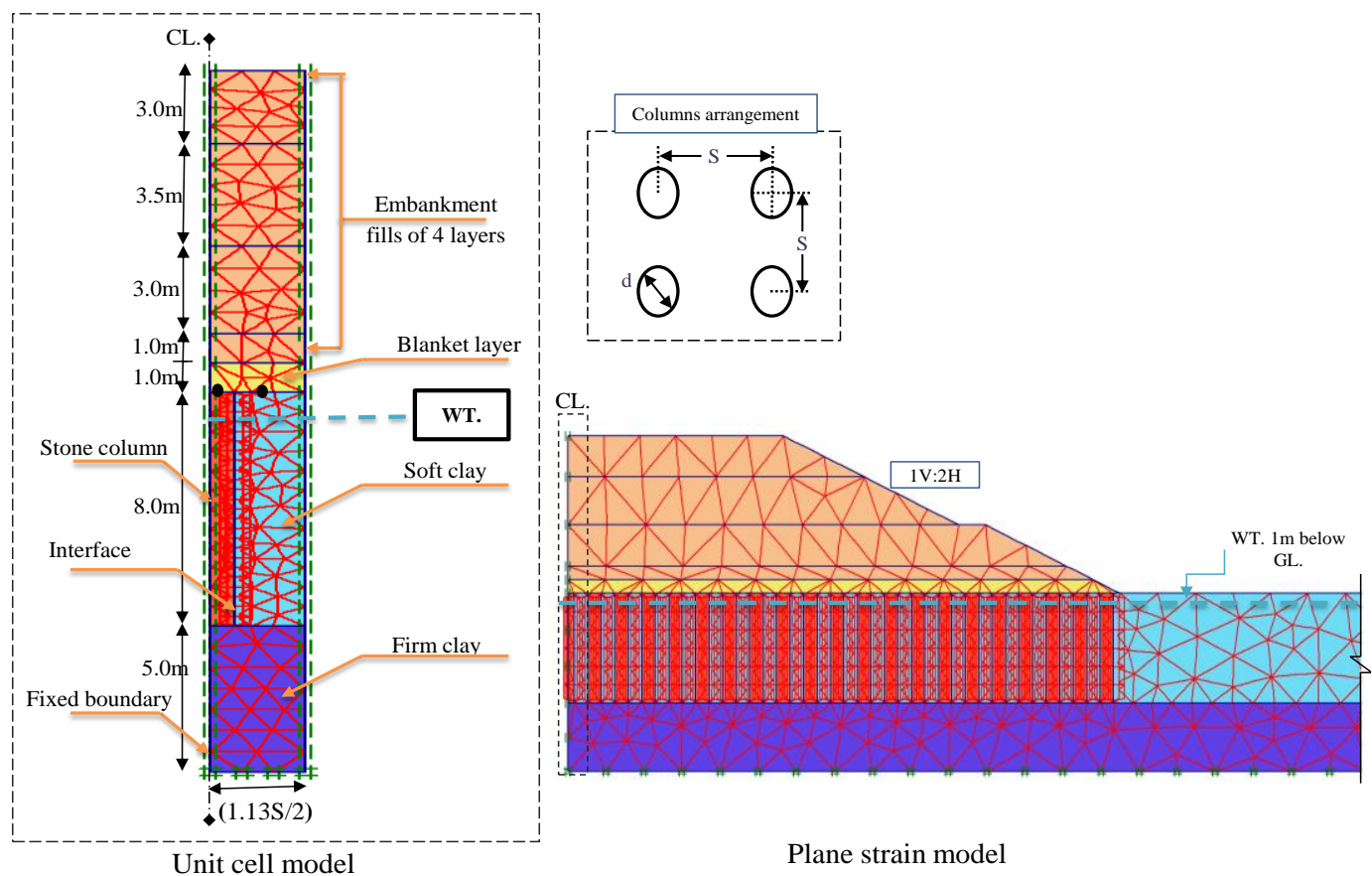

Fig. 1: Cross Sections Showing the Geometry with Fine Mesh of Embankment Project Modeled.

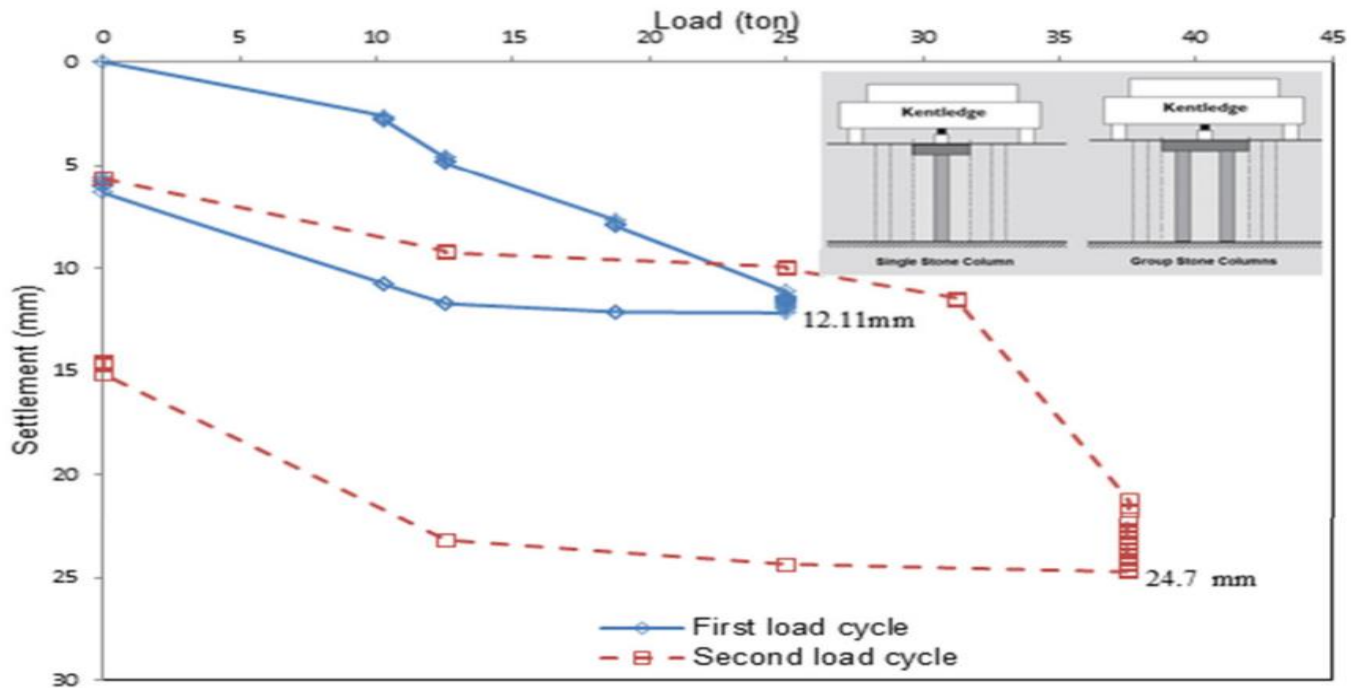

Fig. 2: Load-Settlement Curves of a Single Column Plate Load Test. 


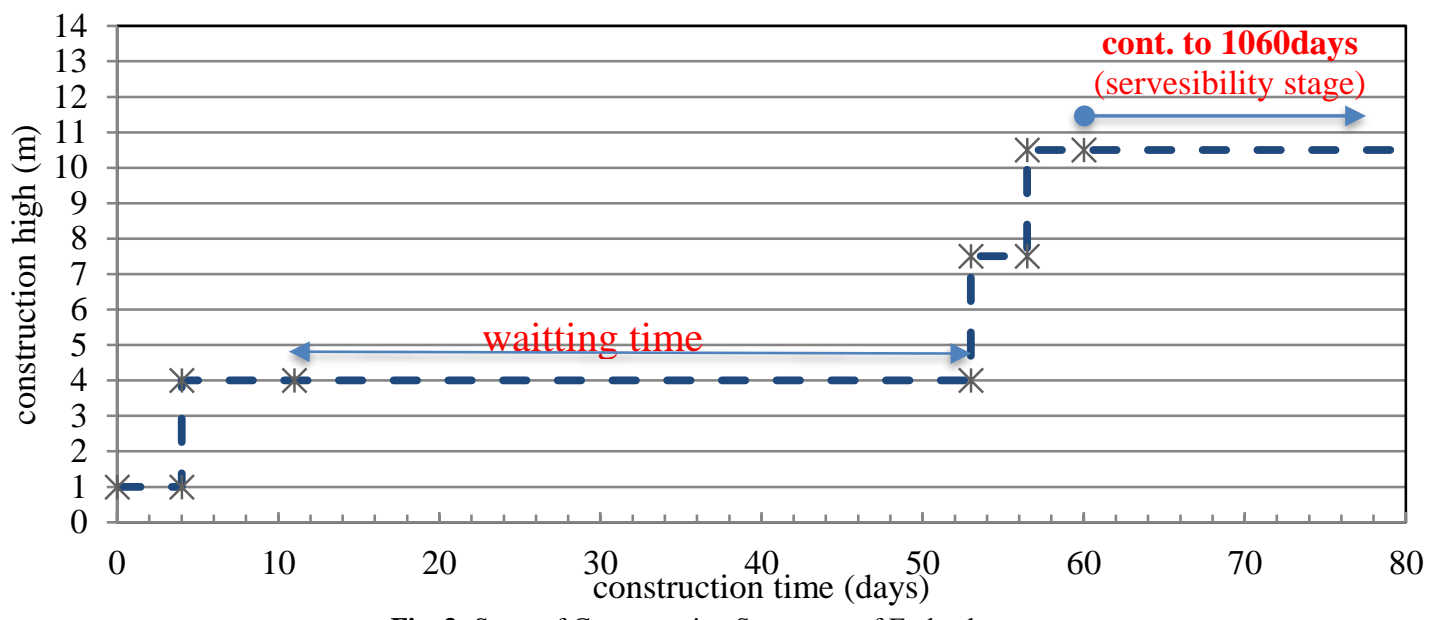

Fig. 3: Stage of Cconstruction Sequences of Embankment.

\section{Numerical modelling and material proper- ties}

Finite element analysis based on the PLAXIS 2D v8.2 package was used to simulate this case study. All the numerical analyses were carried out with regard to the geometry of the unit cell in one and the plane strain in another, with a square arrangement of the stone columns. For the unit cell concept, the circular, isolated columns had an equivalent diameter of influencing area that was equal to $\mathrm{d}_{\mathrm{e}}=1.13 \mathrm{~S}$, where $\mathrm{S}$ is the spacing between adjacent columns. Due to the symmetry in both models (unit cell and plane strain), only half of the cross sections were simulated to save computing time. The Mohr-Coulomb failure criterion was adopted for the materials of all the elements with drained behaviour that were assumed for the stone columns and fill materials, while the undrained soft clay was assumed for the soil. The properties of the soft clay, stone column, and sand can be found in the literature [13]. The input parameters for the Mohr-Coulomb model involved the stiffness modulus (E), drained cohesion (c), internal friction angle $(\varphi)$, dilation angle $(\psi)$, Poisson's ratio $(v)$, and unit weight $(\gamma)$. All these parameters and the interface strength between the stone column and soft clay $\left(\mathrm{R}_{\text {inter }}\right)$ are set out in Table 1 .

Table 1: Soil Data Sets Parameters Used for Validation of PLAXIS

\begin{tabular}{|c|c|c|c|c|c|c|}
\hline \multicolumn{2}{|c|}{ Mohr-Coulomb } & Blanket layer & Fill material & Firm clay & Soft clay & Stone column \\
\hline \multicolumn{2}{|c|}{ Type } & Drained & Drained & Undrained & Undrained & Drained \\
\hline$\gamma_{\text {unsat }}$ & {$\left[\mathrm{kN} / \mathrm{m}^{3}\right]$} & 19 & 17 & 16 & 15 & 12 \\
\hline$\gamma_{\mathrm{sat}}$ & {$\left[\mathrm{kN} / \mathrm{m}^{3}\right]$} & 22 & 18 & 17 & 16 & 22 \\
\hline $\mathrm{k}_{\mathrm{x}}$ & [m/day] & 1 & 1 & $7.36 * 10^{-5}$ & $7.36 * 10^{-5}$ & 1 \\
\hline $\mathrm{k}_{\mathrm{y}}$ & [m/day] & 1 & 1 & $3.68 * 10^{-5}$ & $3.68 * 10^{-5}$ & 0.5 \\
\hline $\mathrm{E}$ & {$\left[\mathrm{kN} / \mathrm{m}^{2}\right]$} & $20 * 10^{3}$ & $20 * 10^{3}$ & $15^{*} 10^{3}$ & $2 * 10^{3}$ & $20 * 10^{3}$ \\
\hline$v$ & {$[-]$} & 0.333 & 0.333 & 0.4 & 0.4 & 0.333 \\
\hline $\mathrm{c}$ & {$\left[\mathrm{kN} / \mathrm{m}^{2}\right]$} & 0.1 & 0.1 & 23 & 28 & 0.1 \\
\hline$\varphi$ & {$\left[{ }^{\circ}\right]$} & 35 & 30 & 28 & 1 & 38 \\
\hline$\psi$ & {$\left[{ }^{\circ}\right]$} & 0.0 & 0.0 & 0.0 & 0.0 & 8 \\
\hline $\mathrm{R}_{\text {inter. }}$ & {$[-]$} & 1 & 1 & 1 & 1 & 1 \\
\hline
\end{tabular}

The mesh and mechanical boundary conditions of the unit cell and plane strain models are included in Figure 1. As far as the displacement boundary is concerned, no displacements in the directions perpendicular to the symmetry planes and to the base were allowed. In the plane strain cross sectional view, the right boundary was assumed to be impervious since there were no flows crossing the symmetry plane. The left boundary was assumed to be impervious as well since it was located far enough to have a minor influence on the results. The bottom was also impervious, thereby accounting for the low permeability of the underlying firm clay. The fine mesh arrangement was generated with fifteen-node triangular elements having three translational degrees of freedom per node to achieve high accuracy at the beginning of the consolidation process in both models (the average number of elements was 290 and 1189 in the unit cell and plane strain models, respectively). The gravity loading was considered to generate the initia stress and pore water pressure, where the phreatic level was set at $1 \mathrm{~m}$ below the top surface.

The soft soil reinforced with ordinary stone columns was investigated using a consolidation analysis during and after each construction stage (this type of analysis should be selected to analyse the dissipation of excess pore water pressure in water-saturated clayey soils as a function of time). The calculation was continued until the excess pore water pressure reached at least $1 \mathrm{kPa}$. The outcomes obtained from the numerical analysis to achieve the purpose of this study were the stress concentration ratio at the ground surface, and the failure mechanism.

\section{Parametric study}

To make the investigation more thorough and representative, a parametric study was conducted through a series of analyses to evaluate the performance of each stone column model used and to investigate the influence of each key factor, as summarized in Table 2.

Table 2: Values of Influence Factors Used

\begin{tabular}{lll}
\hline Item & Parameter & Range of value \\
\hline Stone column & Diameter ratio $(\mathrm{d} / \mathrm{S})$ & $0.4,0.45,0.5,0.55 \& 0.6$ \\
& Internal friction angle $(\varphi)$ & $30,38,40 \& 45$ \\
& c/c spacing ration $(\mathrm{S} / \mathrm{d})$ & $2,2.6,3 \& 3.4$ \\
Soft clay & Undrianed cohesion $(\mathrm{kPa})$ & $15,28,30 \& 35$ \\
\hline
\end{tabular}

\section{Results and discussion}

The effects of the abovementioned factors on the SCR and failure mechanism were evaluated and rated in this study.

\subsection{Failure mechanism and load transfer}


In the FEM of this particular soil body, plastic points were observed at the end of the second construction stage, as shown in Figure 4. Further deformations and strain variations were expected to occur at these points. The use of stone columns with better quality material would deter the occurrence of plastic points due to the material yield limit of the column material [14].

By comparing the plastic point's distribution of the two models, it could be concluded that the unit cell model represented one of the interior columns of the plane strain model but did not represent the exterior column. This was probably one of the limitations of the unit cell, and the benefit of using the plane strain approach to model stone columns, especially in studies of slope stability and failure mechanisms.
Considering the fact that stress redistribution was a key mechanism in this system, and that the properties of the embankment fill and foundation soil were stress dependent, the higher the stress concentration ratio, the more the stress that would be transferred onto the columns. Fig. (5) and Figure 6 display the stress distribution in the system that resulted from the plane strain and unit cell analysis, respectively. The plane strain model showed a reduction in the stress distribution whenever it moved away from the centre, and this observation could not be detected through the use of the unit cell concept. However, the use of the unit cell model resulted in a higher stress transfer to the column than the plane strain model.

\section{口 Plastic points}

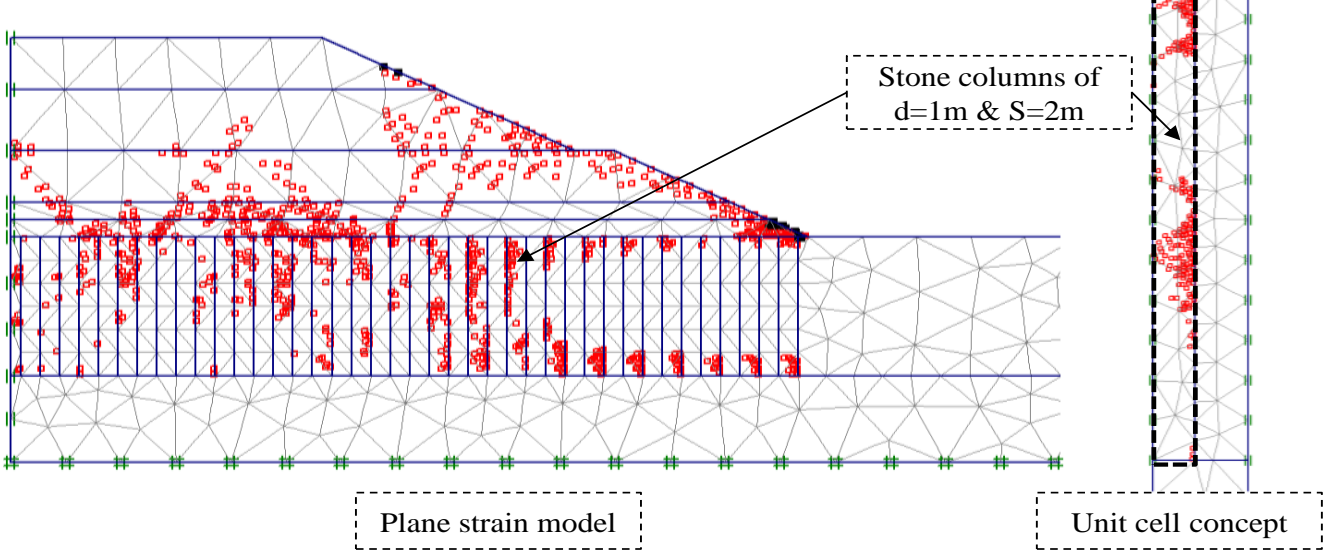

Fig. 4: Plastic Points Distribution at the Consolidation End of the Second Construction Stage in Two Used Models.

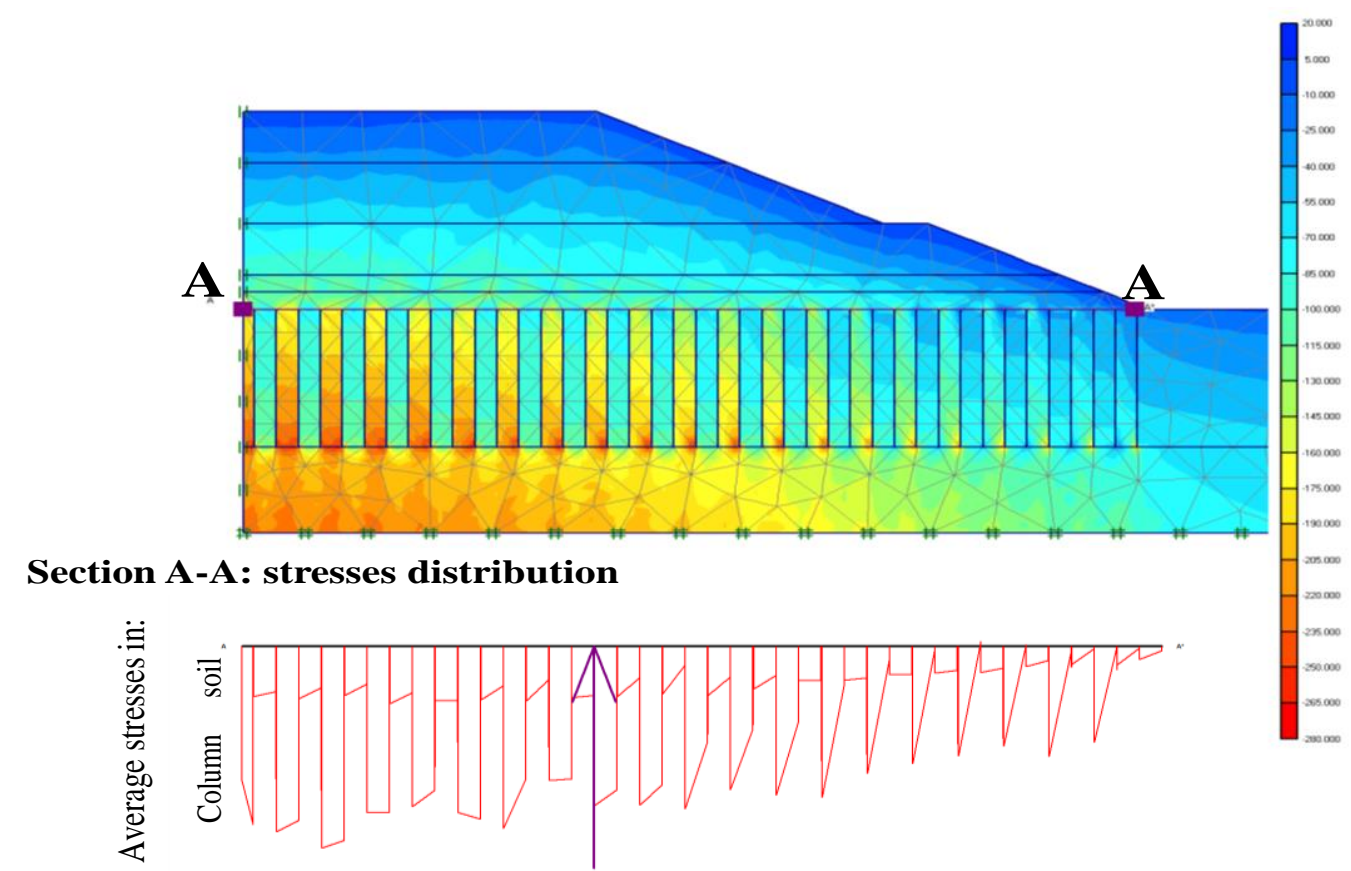

Fig. 5: Stress Distribution Between Stone Columns and Surrounding Soil in Plane Strain Model.

There is a clear difference between the failure modes of a group of stone columns and an isolated column, where the columns can interact and restrain the expansion of the adjacent columns [15]. According to McKelvey et al. [16], in a group of stone columns, the central column deforms or bulges uniformly, whereas the column at the edge bulges away from neighbouring columns, as occurred in the current study (see Figure 7). 


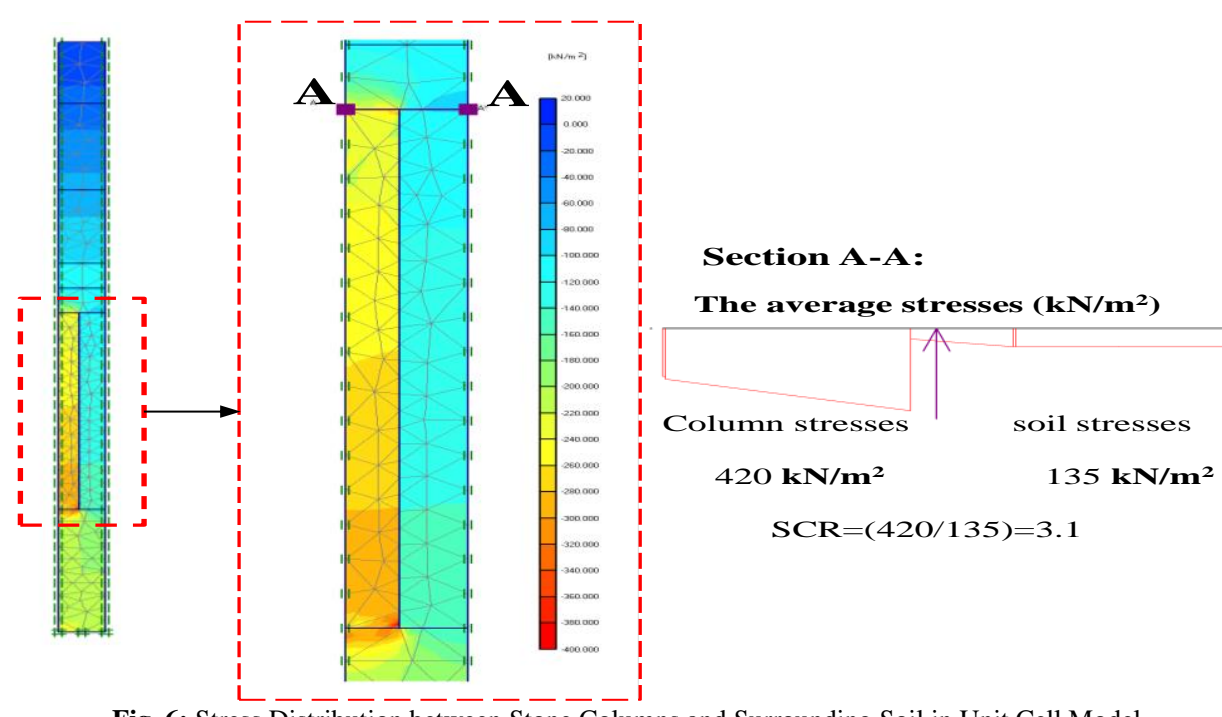

Fig. 6: Stress Distribution between Stone Columns and Surrounding Soil in Unit Cell Model.

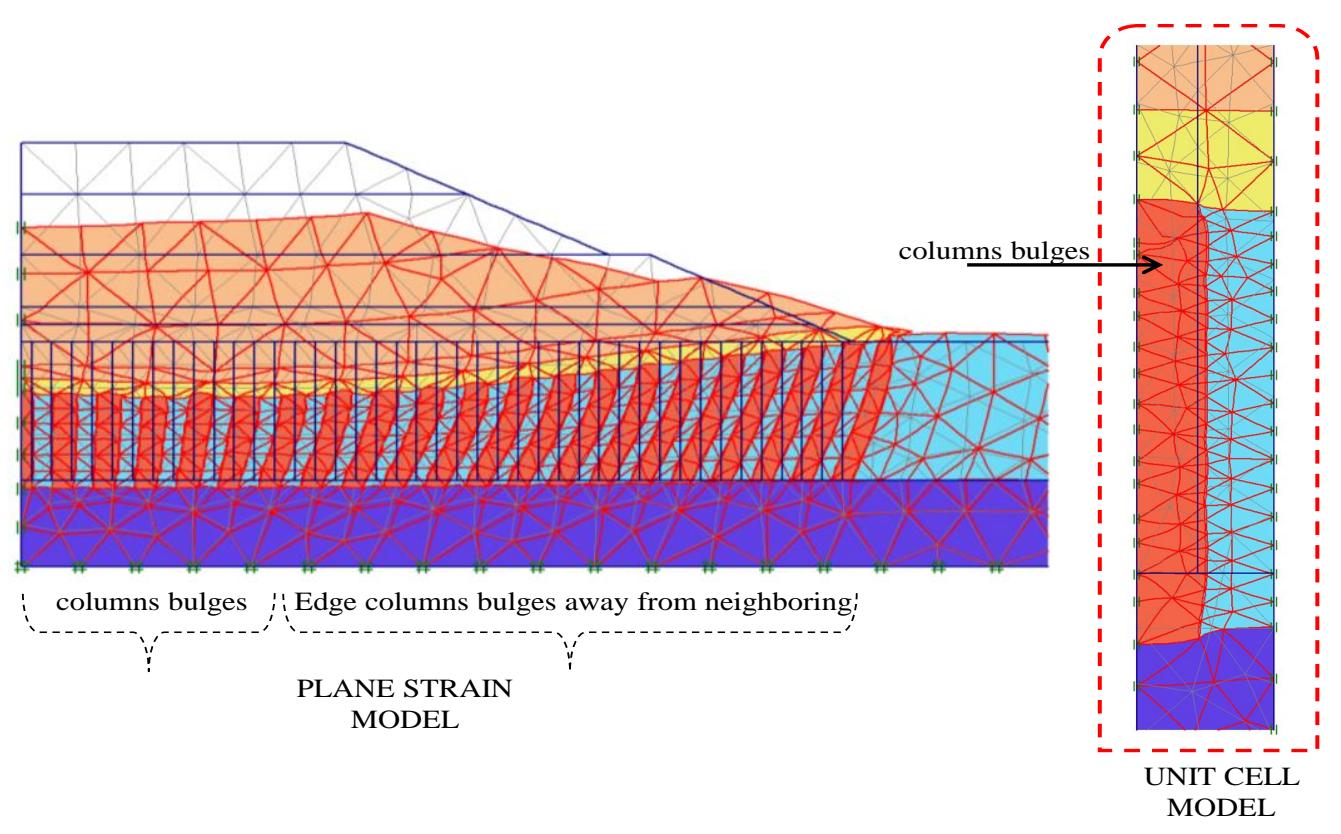

Fig. 7: Deformation Mode of Unit Cell and Plane Strain Models.

\subsection{Stress concentration ratio (SCR)}

As a load is applied on top of stone columns, it will cause an increase in the shear strength of the stone columns and a reduction of settlement in the surrounding soft soil. Thus, the concentration of stress will lead to the stone columns becoming considerably stiffer than the surrounding soil. Since the deformation of the two main materials (stone and soil) is approximately the same, the stress in the stiffer stone column material should be greater than the stress in the surrounding soil in terms of equilibrium.

For the different key factors that were investigated in this study, the developments in the SCR at the surface for both approaches were simulated and compared, as in Figure 8. The SCR changed with some factors, including the spacing ratio (S/d), column diameter ratio $(\mathrm{d} / \mathrm{S})$, friction angle of the stone column, and the undrained cohesion of the soft soil.

The SCR was calculated at the surface of the ground at the end of the last construction stage using the average vertical stresses at the A-A reference section, as presented in Figure 5 and Figure 6. The SCR decreased along the length of the stone column and increased with consolidation time [17]. Since the surrounding soil became stiffer with depth, whilst the column became more yielding, this caused a reduction in the SCR. Therefore, the ground surface was used to evaluate the stress concentration ratio.
Figure 8.a demonstrates the resulting stress concentration values under an increased c/c spacing ratio $(\mathrm{S} / \mathrm{d})$. The ratio of the stress in the column to the surrounding soil was measured to be around 3 and 2.59 at a low spacing ratio, decreasing at the rate of $3 \%$ and $7.8 \%$ when $(\mathrm{S} / \mathrm{d})$ was increased from 2 to 3.4 , based on the unit cell and plane strain analysis, respectively. Ambily and Gandhi [5] stated that the use of the unit cell concept with a small c/c spacing ratio gives questionable results.

The relationship between the SCR and the column diameter was plotted in Figure 8.b. The outcomes from the plane strain model indicated a gradual increase in the SCR at a rate of about $10 \%$ as the diameter of the stone column increased from $0.4 \mathrm{~S}$ to $0.6 \mathrm{~S}$, while the unit cell model showed a slight increase in the rate of the SCR with changes in the diameter of the column. The SCR reached a higher value of 2.77 when $\mathrm{d} / \mathrm{S}=0.6$ and 3.088 in the plane strain and unit cell models, respectively.

The different developments in the SCR at the ground surface in both approaches were simulated, as shown in Figure 8.c, for various values of the friction angle of the stone column. When the friction angle of the column was increased, there was a rapid increase in the SCR, especially in the plane strain model, where the rate increased by up to $66 \%$ as the friction angle was increased from $30^{\circ}$ to $45^{\circ}$. The SCR reached the maximum value of 3.144 and 2.93 when $\varphi=45^{\circ}$ in the plane strain and unit cell models, respectively. 
Figure 8.d shows the results of the SCR versus the shear strength of soft clay from an analysis of the unit cell and plane strain models. The SCR trends for both models were approximately similar, which showed that the stress concentration ratio reduced as the undrained cohesion of the soil increased. This phenomenon was due to the increase in the stiffness of the surrounding soft soil. The increase in the overall stiffness of the surrounding soil led to a reduction in the stress concentration in the column and in the stress transfer from the surrounding soil. When the soft soil had a cohesion of $28 \mathrm{kPa}$ or more, there was no significant change in the SCR, and it was almost constant, based on the two approaches used in the current work. The difference between the two models became smaller, changing from $3.3 \%$ to $2.7 \%$ and $2.6 \%$, as the undrained cohesion values of the soft clay became higher from $28 \mathrm{kPa}$ to 30 and $35 \mathrm{kPa}$, respectively. Ambily and Gandhi [5] carried out laboratory tests on the stone column group model, and finite element analyses on the single and group columns. The results, which were similar to the results of the current study, showed that the stress concentration ratio decreased as the shear strength of the surrounding soil increased.

(a)

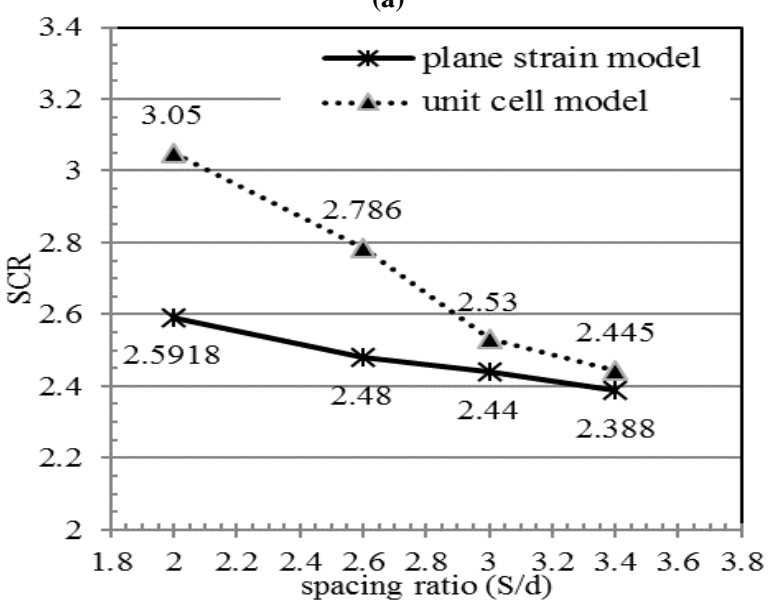

(b)

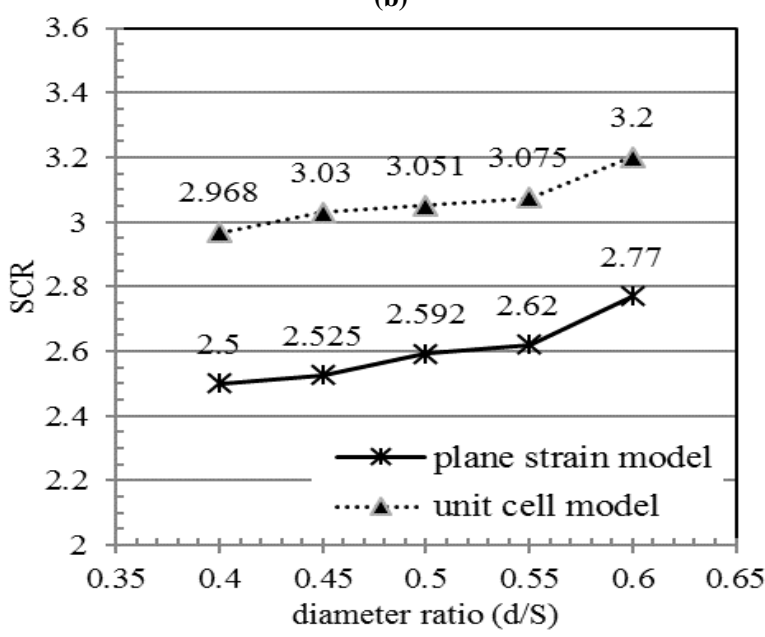

(c)

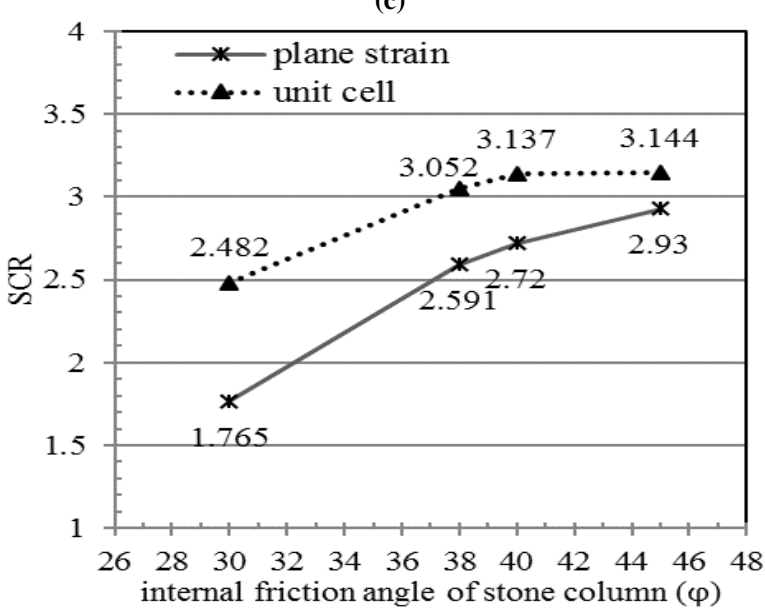

(d)

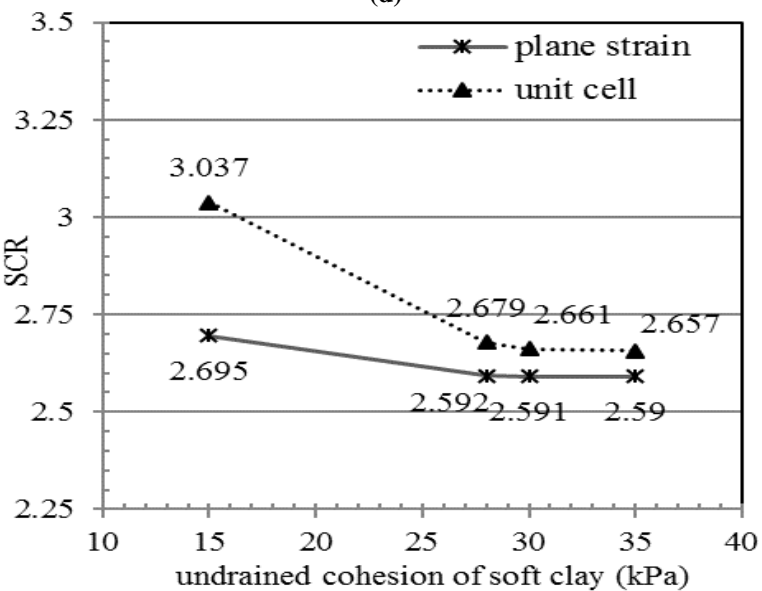

Fig. 8: Factors Influencing SCR: (a) c/c Spacing Ratio (S/d); (b) Stone Column Diameter Ratio (d/S); (c) Friction Angle of Stone Column Material; (d) Undrained Cohesion of Soft Clay.

Within the scope of this study, the stress concentration ratio varied from 1.76 to 2.93 and 2.48 to 3.14 , with an average of 2.56 and 2.95 in the plane strain and unit cell concept, respectively. Barksdale and Bachus [18] reported that the stress concentration ratio below an embankment supported by a square grid of stone columns has an average value of 2.8 , which is close to the result of this study. The SCR was observed to decrease with increasing c/c spacing ratio as well as increasing surrounding soil strength, while increasing the column diameter and friction angle of the column led to an increase in the SCR.

\section{Conclusions}

The present study investigated the accuracy of two types of model systems, namely, the individual stone column (unit cell model) and a group of stone columns (plane strain model) by means of a numerical analysis. The following conclusions were derived from the current study:

1) The stress concentration ratio was found to be slightly higher in the unit cell model than in the plane strain model. The SCR was found to lie between $1.76_{\sim} 2.93$ for the plane strain model, and between 2.48 3.14, for the unit cell model.

2) From the results that were obtained, the use of the unit cell model indicated that the stress transferred to the column was greater compared to the plane strain model.

3) Finally, it was concluded that the unit cell concept seems to be unsuitable for use in some stone column studies, such as for studies into failure mechanisms. 


\section{Acknowledgments}

The authors gratefully acknowledge the financial support provided by Development of Affordable and Innovative Earthquake Resistance System for Low-Rise Residential Building-Universiti Kabangsaan Malaysia UKM under research grant AP-2015-011in this work.

\section{References}

[1] N. P. Balaam, and I. R. Booker, Analysis of rigid rafts supported by granular piles, International Journal for Numerical and Analytical Methods in Geomechanics, Vol.5, No.4, (1981). 379-403. https://doi.org/10.1002/nag.1610050405.

[2] W. Y. Van Impe, and E. De Beer, Improvement of settlement behavior of softy layers by means of stone columns. Proc. $8^{\text {th }}$ International Conference on SMFE, Helsinki, (1983). 309-312.

[3] H. Aboshi, E. Ichimoto, M. Enoki and K. Harada, the "Compozer" a method to improve characteristics of soft clays by inclusion of large diameter sand columns. In: Proceeding of $1^{\text {st }}$ International Conference on Soil Reinforcement, Paris, (1979), 211-216.

[4] R. R. Goughnour and A. A. Bayuk, A field study of long term settlements of loads supported by stone columns in soft ground. Proceedings of the International Conference on Soil Reinforcement, Paris, (1979), 279-285.

[5] A. P. Ambily and S. R. Gandhi, Behavior of stone columns based on experimental and FEM analysis. Journal of Geotechnical and Geoenvironmental Engineering, Vol.133, No.4, (2007), 405-415. https://doi.org/10.1061/(ASCE)1090-0241(2007)133:4(405).

[6] D. A. Greenwood, Load tests on stone columns. In: Deep Foundations and Improvements, Design, Construction and Testing, $\quad$ ASTM 1089, (1991), 148-171. https://doi.org/10.1520/STP25057S

[7] S. W. Abusharar and J. Han, Two-dimensional deep-seated slope stability analysis of embankments over stone column-improved soft clay, Journal of Engineering Geology, Vol.120, No. (1-4), (2011), 103-110.

[8] K. S. Ng, Numerical study and design criteria of floating stone columns. Dissertation, National University of Singapore, Singapore, (2014).

[9] E. Ichmoto, Results of design and construction of sand compaction pile method." In: $36^{\text {th }}$ JSCE conference discussion, (1981), 51-55.

[10] T. W. Kim, Numerical analysis of the behavior of sand compaction pile in clay. Master thesis, Dankook University, (2001). (in Korean).

[11] K. S. Watts and C. J. Serridge, A trial of vibro bottom-feed stone column treatment in soft clay soil. In: Proceeding, 4th international conference ground improvement geosystems, Helsinki, (2000). $549-556$

[12] D. T. Bergado, Panichayatum, and C. L. Sampaco, Reinforcement of soft bangkok clay using granular piles. In: Proceedings, international symposium on theory and practice of earth reinforcement, Kyushu, (1988). 179-184.

[13] Adnan Qasim, Behavior of stone column embedded in soft clays under embankment by using finite element and artificial intelligent methods, Phd thesis Universiti Kebangsaan Malaysia, (2014).

[14] K. S. Ng, Settlement ratio of floating stone columns for small and large loaded areas. Journal of GeoEngineering, Vol.12 No.2, (2017). 89-96.

[15] Dheerendra Babu, M. R., S. Nayak, and R. Shivashankar, A Critical Review of Construction, Analysis and Behaviour of Stone Columns. Journal of Geotechnical and Geological Engineering, Vol.31 No.1, (2013), 1-22. https://doi.org/10.1007/s10706-012-9555-9.

[16] D. McKelvey, V. Sivakumar, A. Bell and J. Graham, Modelling vibrated stone columns in soft clay." In: Proceedings of the institute of civil engineers geotechnical engineering, (2004), 137-149.

[17] H. D. Golakiya and M. D. Lad, Ground improvement by using stone column. Journal of Emerging Technologies and Innovative Research (JETIR), Vol.2 No.11, (2015) 133-144.

[18] R. D. Barksdale and R. C. Bachus, Design and construction of stone columns. Report No. FHWA/RD-83/026, National Technical Information Service, Virginia, USA (1983). 